\title{
A Study of Academic Stress among Senior Secondary Students
}

\author{
Kartiki Porwal*, Dr. Ravindra Kumar**
}

\begin{abstract}
The main objective of the present study is to examine the academic stress among senior secondary students. The total participants of the study were 30 (15 male and 15 female). All students belong to 12 th standard studying in Noida. The Data was collected through standardized Academic Stress Questionnaire (ASQ) by Akram, Mohd Ilyas Khan and Sahiba Baby. Mean, Standard deviation and T-test were conducted for analysis of data. Result indicates that there is significant difference among boys and girls in relation to academic stress. Result revealed that senior secondary boys have higher academic stress in compare to girls.
\end{abstract}

KEYWORDS: Stress, Academic Stress, senior secondary boys and girls.

\section{INTRODUCTION:}

Academic stress is the anxiety and stress that comes from schooling and education .There is a lot of pressure that comes along with pursuing their education. Students report experiencing academic stress at predictable times each semester with the greatest sources of academic stress resulting from taking and studying for exams, grade competition, and the large amount of content to master in a small amount of time(Abouserie, 1994).There are lot of stress related to studies, homework, tests, reading, tuition and other academic competitions student faces a lot of stress due to imbalance of academic and social performance and time management for extracurricular activities from education. Academic stress is especially high in the students who are unable to maintain balance between their academic, family, and friend, social and academic activities in life. Stress is very common as they are more worried about their carrier. Student stress level also depends a lot on attitude of teachers towards them. Fear of academic failure related to these tasks is a definite stressor (Kolko, 1980). If a teacher is friendly then the student has less stress while-

\footnotetext{
*M.A Student, Indian Institute of Psychology, Noida, Uttar Pradesh

**Assistant Professor, Department of Psychology, Mewar University, Chittorgarh, Rajasthan
} 
talking to them related to their academics. Whereas teachers who are not very friendly then students doesn't feel that comfortable due to fear which generally arises due to stress. This phenomenon has created certain dependable situations among students. In such situation a student depends more on tuition rather than school teachers. If the tuition- teacher is not able to understand the problem of the student than it leads to stress level so high that the student slowly starts to lose interest in studies. The stress level among students varies when work is given as challenges or threat. The pressure to perform well in the examination or test and time allocated makes academic environment very stressful. Erkutlu \& Chafra (2006) explained that if the work is given as the challenge then the stress level lowers due to the competition among the students to achieve the target provided if the work is given in small amount and if the completion of work is not required in an allocated time. Whereas if the work is given and student are threatened to complete the work in a limited time then the stress level in students is found to be very high and only few student are able to complete the given task. The stress levels of student vary according to behavior of teachers and according to the school environment. The stress level of students studying in schools which promote or give importance to co-curricular activities such as sports, dance, music, swimming art is low as compared to student studying in school which don't promote these co-curricular activities instead they promote co-curricular activity related to education such as debate, quiz, speech etc and general feeling among such school are that sports is rubbish and are less focused and promoted.

Now a day's yoga, kung fu, karate etc are being introduced to minimize the stress level among the students. The yoga plays an important role in keeping the stress level down and also helps to improve the concentration power in students. Moreover, importance should $b$ given to the above mentioned co-curricular activities more and more over stress level will automatically become low when students are healthy. So, such steps should be taken by schools to improve the performance of their students with a friendly environment.

\section{OBJECTIVE OF THE STUDY:}

The main objective of the study is to examine the academic stress among senior secondary students. 


\section{HYPOTHESIS OF THE STUDY:}

There is no significant difference among senior secondary boys and girls in relation to academic stress.

\section{RESEARCH METHODOLOGY:}

\section{Sample}

The research sample consisted of thirty participants divided into two groups. Group A consists of 15 girls and Group B consists of 15 boys of senior secondary school. All belong to the secondary level age 17-19 years. All participants were from school of Noida.

Table I

Sample of Senior Secondary Boys and Girls

\begin{tabular}{|c|l|c|c|}
\hline Sr. No. & \multicolumn{1}{|c|}{ Group } & N & $\sum$ \\
\hline $\mathbf{1 .}$ & Boys & 15 & 30 \\
\hline $\mathbf{2 .}$ & Girls & 15 & \\
\hline
\end{tabular}

Tools used

The data was collected through standardized "Academic stress questionnaire" by Mohad Akram, Mohd Ilyas Khan and Sahiba baby. This tool has only 36 items. There was no time limit of the test. Reliability of the test is 0.829 and the validity of the test is 0.41 to 0.88 .

\section{Procedure of Data Collection}

There were 30 participants selected from the school of Noida. The data was collected with the help of the teachers. Detailed instruction were given to all the participants, how to fill the scoring sheet. Participants have done the test in peaceful environment with full concentration.

\section{STATISTICAL ANALYSES AND RESULT:}

The entire data were coded for analyses the data, statistics and t-test for mean difference were applied to measure stress management scale. All the calculations were calculated manually. 
The International Journal of Indian Psychology: Volume: 01 | Issue: 03 | ISSN 2348-5396

\section{Table II}

Mean S.D and T-value of Senior Secondary Boys and Girls.

\begin{tabular}{|c|c|c|c|c|c|c|}
\hline Sr. No. & Group & N & Mean & S.D & T-test & Sig \\
\hline 1. & Boys & 15 & 64.46 & 8.02 & \multirow{2}{*}{3.23} & S \\
\hline 2. & Girls & 15 & 57.66 & 7.59 & & \\
\hline
\end{tabular}

The results show that boys have higher scores on academic stress than girls. Boys mean is $(\mathrm{M}=64.46, \mathrm{SD}=8.02)$ in relation to Academic stress. Results represent that boys have more academic stress in their academic work in compare to girls $(\mathrm{M}=57.66, \mathrm{SD}=7.59)$. It may be due to have a lot of diverse work pressure than the girls. The t-value is 3.23 which is significant. So, here we reject Null Hypothesis $\left(\mathrm{H}_{0}\right)$.

\section{DISCUSSION AND CONCLUSION:}

It is generally found that stress level have been found more in boys than girl as shown in the study. Boys have more stress due to the fact that parents have a feeling that boys are more capable of handling their property and business including other household and social responsibility, family has higher expectation from the males to excel in life, rather than girls. Due to this fact parents expect more from boys rather as compared to girls, which is a major cause of increasing stress level in boys. Youth suicide, however, is only the tip of the iceberg, which masks the generalized anxiety and depression experienced by many high school students. Studies Conducted in Korea and Japan have found that students who experience academic stress. Express their distress in a variety of ways, including in terms of depression, anxiety, and Somatic symptoms (Lee \& Larson, 1996; Schoolland, 1990) Some students are not capable of handling so much stress and they find it easier to die rather than living a life full of stress. As a result suicide rate among youth is increasing at a fast rate. Moreover parent's expectation on their children is increasing day by day which is another cause of increasing stress level among youth. For example parents wish that his son or daughter should become engineer or doctor without knowing their children ambitions like he or she may have interest in other fields but parents pressurize their children to fulfill their wish. Sometime the parents are influenced by the society in which they are living. All these factors affect boys more than girls as boys are believed to settle or manage a family 


\section{LIMITATION OF THE STUDY:}

A limited number of subjects have been considering in this research. For a more profound evaluation higher number of subjects from diverse backgrounds is more welcome step. Students of 12th class go through huge and diverse social academic changes and are susceptible to numerous behavioral changes. Taking notice of these changes is the biggest challenge.

\section{REFERENCES:}

1. Abouserie, R. (1994). Sources and levels of stress in relation to locus of control and self esteem in university students, Educational Psychology, 14 (3) pp-323-330

2. Carveth, J.A., Gesse, T., \& Moss, N. (1996). Survival strategies for nurse Midwifery students, Journal of Nurse-Midwifery, 41 (1) 50-54

3. Erkutlu HV, Chafra J (2006). Relationship between leadership power bases and job stress of subordinates: example from boutique hotels, Management Research News, 29 (5) pp285-297

4. Kolko, David J. (1980). Stress Management Techniques for Graduate Students: Cognitive Coping, Problem Solving and Time Management, The South-eastern Psychological Association, March, 1980, Washington, D.C. ED 192230. 